\title{
Epidemiological study of hepatitis B and C in a municipality with rural characteristics: Cássia dos Coqueiros, State of São Paulo, Brazil
}

\author{
Laura Valdiane Luz Melo ${ }^{[1],[2], ~ M a r c o n d e s ~ A l v e s ~ B a r b o s a ~ d a ~ S i l v a ~}{ }^{[2],}$ \\ Gleici da Silva Castro Perdoná[1], Margarida Maria Passeri Nascimento ${ }^{[1]}$, \\ Marie Secaf ${ }^{11}$, Rosane Aparecida Monteiro ${ }^{[1]}$, Ana de Lourdes Candolo Martinelli ${ }^{[1]}$ \\ and Afonso Dinis Costa Passos ${ }^{[1]}$
}

[1]. Departamento de Medicina Social, Faculdade de Medicina de Ribeirão Preto, Universidade de São Paulo, Ribeirão Preto, São Paulo, Brasil. [2]. Instituto de Ciências Exatas e Naturais, Curso de Medicina, Universidade Federal de Mato Grosso, Rondonópolis, Mato Grosso, Brasil.

\begin{abstract}
Introduction: Hepatitis B and C viral infections remain an important cause of global morbidity and mortality. Studies have been conducted in population groups of large cities, leaving gaps in the knowledge regarding the situation in small municipalities. We aimed to measure the prevalence of hepatitis B and C markers and presence of infection-associated factors. Methods: All inhabitants of Cássia dos Coqueiros aged $\geq 18$ years who agreed to participate in the research were included. We collected blood as well as information via a questionnaire between March 2011 and December 2013. Univariate and multivariate analyses were conducted. Results: Among the 1,001 participants, 41 (4.1\%) participants had a serological profile of hepatitis B viral exposure, and only one $(0.1 \%)$ participant was considered a virus carrier. The frequency of isolated antibody to hepatitis B virus surface antigen (anti-HBs) markers was $17.8 \%$ for the overall population. In the multivariate analysis, hepatitis B virus (HBV) infection was associated with age, birth outside the State of São Paulo, history of hepatitis, $\geq 2$ sexual partners in the last 6 months, and tattoos. Four ( $0.4 \%$ ) participants had a serological profile of hepatitis $\mathrm{C}$ viral exposure. However, after confirmation using viral ribonucleic acid (RNA) evaluation, only one $(0.1 \%)$ individual remained positive. Conclusions: The positivity rates for hepatitis $\mathrm{B}$ and $\mathrm{C}$ were low, despite greater sexual freedom and the recent emergence of illicit drugs, as observed by the health personnel working in Cássia dos Coqueiros.
\end{abstract}

Keywords: Epidemiology. Hepatitis B. Hepatitis C. Prevalence. Risk factors.

\section{INTRODUCTION}

Despite the recent advances in the diagnosis, treatment, and prevention of hepatitis $\mathrm{B}$ and $\mathrm{C}$, they remain important causes for morbidity and mortality worldwide. As a result, they represent a serious public health problem, especially in developing countries ${ }^{(1)}$.

According to the World Health Organization (WHO), more than 2 billion people (one third of the world population) had contact with the hepatitis B virus (HBV) and/or hepatitis $\mathrm{C}$ virus (HCV) at some point in their lives, approximately 400 million people are chronic carriers, and $>600,000$ people die annually

Correspoding author: Dra. Laura Valdiane Luz Melo. Instituto de Ciências Exatas e Naturais/Curso de Medicina/Universidade Federal de Mato Grosso. Rodovia MT-270 Km 06, Sagrada Família, 78735-901 Rondonópolis, Mato Grosso, Brasil.

Phone: 5566 3410-4004; 5566 3022-3086

e-mail: lauravaldiane@hotmail.com

Received 14 July 2015

Accepted 27 October 2015 from these diseases ${ }^{(2)}$. In addition, chronic infection with $\mathrm{HBV}$ or $\mathrm{HCV}$ and the associated complications have important economic consequences, including loss of working hours and increased domiciliary and hospital treatment costs, such as those related with liver transplantation in end-stage disease ${ }^{(3)(4)}$.

The Brazil Health Ministry estimates that at least $15 \%$ of the Brazilian population had contact with $\mathrm{HBV}$, and $1 \%$ of the population has a chronic HBV-related disease ${ }^{(5)}$. According to the Epidemiological Surveillance Reports, approximately 500 individuals die annually in the country from HBV infection; however, considering the occurrence of asymptomatic infection in many people and insufficient notification of symptomatic infections, the frequency of hepatitis B in Brazil is likely underestimated ${ }^{(5)}$.

Hepatitis $\mathrm{C}$ virus is characterized by a silent evolution in most infected individuals (about 80\%) and produces chronic infections that frequently result in liver cirrhosis and hepatocellular carcinoma $(\mathrm{HCC})^{(6)(7)}$. According to the WHO, 3-4 million people are infected with HCV, and 350,000 patients die each year worldwide ${ }^{(7)}$.

Despite the considerable relevance for public health, population-based studies of hepatitis B and C are still 
limited among people with different social, economical, and geographical characteristics, particularly in small communities located in remote areas ${ }^{(8)}$.

In Cássia dos Coqueiros, a large population-based study of hepatitis B was conducted between 1986 and $1990^{(8)}$ and included $70 \%$ of the residents. The prevalences of infection markers were very low: $0.10 \%$ for hepatitis B surface antigen (HBsAg), 1.69\% for hepatitis B surface antibody (anti-HBs), and $7.74 \%$ for antibody to hepatitis B core antigen (anti-HBc). The current investigation aimed to update the prevalence of hepatitis B 25 years after this pioneering study and to investigate the prevalence of hepatitis $\mathrm{C}$, a disease not yet researched in this municipality.

\section{METHODS}

\section{Study design}

This cross-sectional seroepidemiological study sought to determine the prevalences of hepatitis $\mathrm{B}$ and $\mathrm{C}$ markers and presence of possible risk factors. Participants completed a structured questionnaire for sociodemographic variables and risky behaviors for HBV and HBC infections, and a blood sample was collected for laboratory analysis of viral markers.

\section{Study area}

The study was conducted in the municipality of Cássia dos Coqueiros, in the Eastern part of State of São Paulo, Brazil. It is located $351 \mathrm{~km}$ from the state capital, with an area of $191,683 \mathrm{~km}^{2}$ and 13.7 inhabitants per $\mathrm{km}^{2}$. The 2,640 inhabitants are distributed between the urban and rural areas. The main economic activities are subsistence and livestock agriculture ${ }^{(9)}$. Due to its demographic, social, and economic characteristics, Cássia dos Coqueiros could be considered as representative of a large number of small Brazilian municipalities.

\section{Study population}

Prior to recruitment, the study was announced to the Cássia dos Coqueiros inhabitants by means of routine monthly home visits by the community health personnel working in the Family Health Program team, which covers the totality of the population. Everyone attending the unique municipal Health Center for medical care between March 2011 and December 2013 was initially invited to participate. In addition, potential participants were contacted at popular events, community clubs, and home visits throughout 2013, both in urban and rural areas.

Local residents aged $\geq 18$ years who signed an informed consent form (ICF) were included. Participants who did not complete the questionnaire or did not have a blood sample collected or did not sign the ICF were excluded.

\section{Data collection}

Participants were interviewed face to face by a trained researcher in a private place, with an average interview time of $10 \mathrm{~min}$. A paper-based questionnaire, with 50 questions for demographic and socioeconomic variables as well as risk factors for hepatitis B and C, was used for data collection. This questionnaire was tested and standardized during a previous study by the same research group.

The economic situation of the interviewees was classified according to the Criteria Brazil Economic Classification ${ }^{(10)}$ (A1, A2, B1, B2, C1, C2, D, E) depending on the individual/family purchasing power and educational level of the head of the family.

\section{Blood collection}

After the interview, a blood sample was collected by venipuncture and matched with the correspondent questionnaire by numerical codes. Samples were transported to the Serology Laboratory of the Clinical Hospital of the Ribeirão Preto Medical School, where they were centrifuged and stored at $-20^{\circ} \mathrm{C}$. Enzyme immunoassay tests were initially performed for each sample to detect the markers anti-HCV, HBsAg, anti$\mathrm{HBs}$, and total anti-HBc. Enzymatic testing for viral replication marker (HBeAg) and its antibody (anti-HBe) were conducted with the HBsAg-positive samples.

Automated equipment (Architect i2000 SR - Abbott Laboratories) was used for the chemiluminescence immunoassay of magnetic microparticles. All reagents were produced by Abbott Laboratories (HBsAg and anti-HBs: Abbott Diagnostics Ireland Division, Ireland; total IgG anti-HBc and anti-HCV: Abbott Max-Planck-Ring 2, Germany). Detection of hepatitis $B$ virus-deoxyribonucleic acid (HBV-DNA) [VERSANT HBV DNA 3.0 Assay (Bayer-bDNA)] was conducted for the HBsAgpositive serum, and qualitative detection of hepatitis $C$ virusribonucleic acid (HCV RNA) [Amplicor version 2.0 (Roche)] was performed for the anti-HCV-positive serum or potentially positive serum.

\section{Statistical analyses}

Data obtained through the questionnaire and laboratory blood analyses were coded, entered into a database, and transferred to a statistical package (Stata 9.0; College Station, TX, USA). Univariate analysis was performed to determine associations between potential risk factors and the presence of serological markers. Variables with a significance value of $\mathrm{p} \leq 0.20$ were subsequently included in multivariate logistic regression analysis to test for possible associations between risk factors and the presence of markers, and the odds ratios and their confidence intervals are reported.

\section{Ethical considerations}

This study was approved by the Ethics Committee of the Ribeirão Preto Clinical Hospital. Results were kept confidential and personally delivered to each participant. The HBV and/or $\mathrm{HCV}$-infected individuals who required medical attention were directed to Hepatitis Ambulatory of the Clinical Hospital of the Ribeirão Preto Medical School. 


\section{RESULTS}

The study population consisted of 1,001 participants, corresponding to $51.9 \%$ of the initially estimated population for the selected age groups. Lack of participation was mainly due to the fact that potential participants did not attend the health unit during the investigation and/or could not be found at their homes.

Most of the participants were women (60.6\%), lived in the urban area $(69 \%)$, and were born in the State of São Paulo (75\%) (Table 1). The mean age was 46.7 years (range, 18-97 years). Most of the 250 migrants $(76.4 \%)$ were from the State of Minas Gerais, and $85.2 \%$ of them had resided $>10$ years in Cássia dos Coqueiros. Regarding education level, 52.5\% had an incomplete primary education; the economic situation was classified as $\mathrm{C} 1$ or $\mathrm{C} 2$ for $58.1 \%$ of the participants.

The laboratory investigations showed that 41 (4.1\%) participants had anti-HBc, which is indicative of prior exposure to hepatitis B (Table 2), and 32 also had anti-HBs, indicating recovery from a previous infection. Only one $(0.1 \%)$ participant had HBsAg, with concomitant positivity for anti-HBc. Isolated anti-HBs were present in 178 (17.8\%) participants. Thus, 41 participants were considered positive for $\mathrm{HBV}$, resulting in a total prevalence of $4.1 \%$ (95\% CI: $3.0-5.5)$, and four $(0.4 \%)$ individuals tested positive for $\mathrm{HCV}$.

Positive samples for HBsAg and anti-HCV were tested using molecular biology techniques, confirming the positive HBsAg result and one of the four positive HCV results, which was identified as genotype 3. Positivity to hepatitis B increased with age (Figure 1A), ranging from $0 \%(<25$ years old) to $8.4 \%$ (55-64 years old) $(\mathrm{p}=0.009)$.

Although the participants' immunization cards could not be accessed, the positivity for only anti-HBs in the 178 participants was considered the result of previous vaccination. A progressive decline in anti-HBs positivity was observed with increasing age $(p=0.00001$; Figure 1B).

Infection was more common among men (5.6\%) than among women in the univariate analysis (3.3\%), but this result

TABLE 1 - Sociodemographic characteristics of the study participants in Cássia dos Coqueiros, State of São Paulo, $2011-2013$.

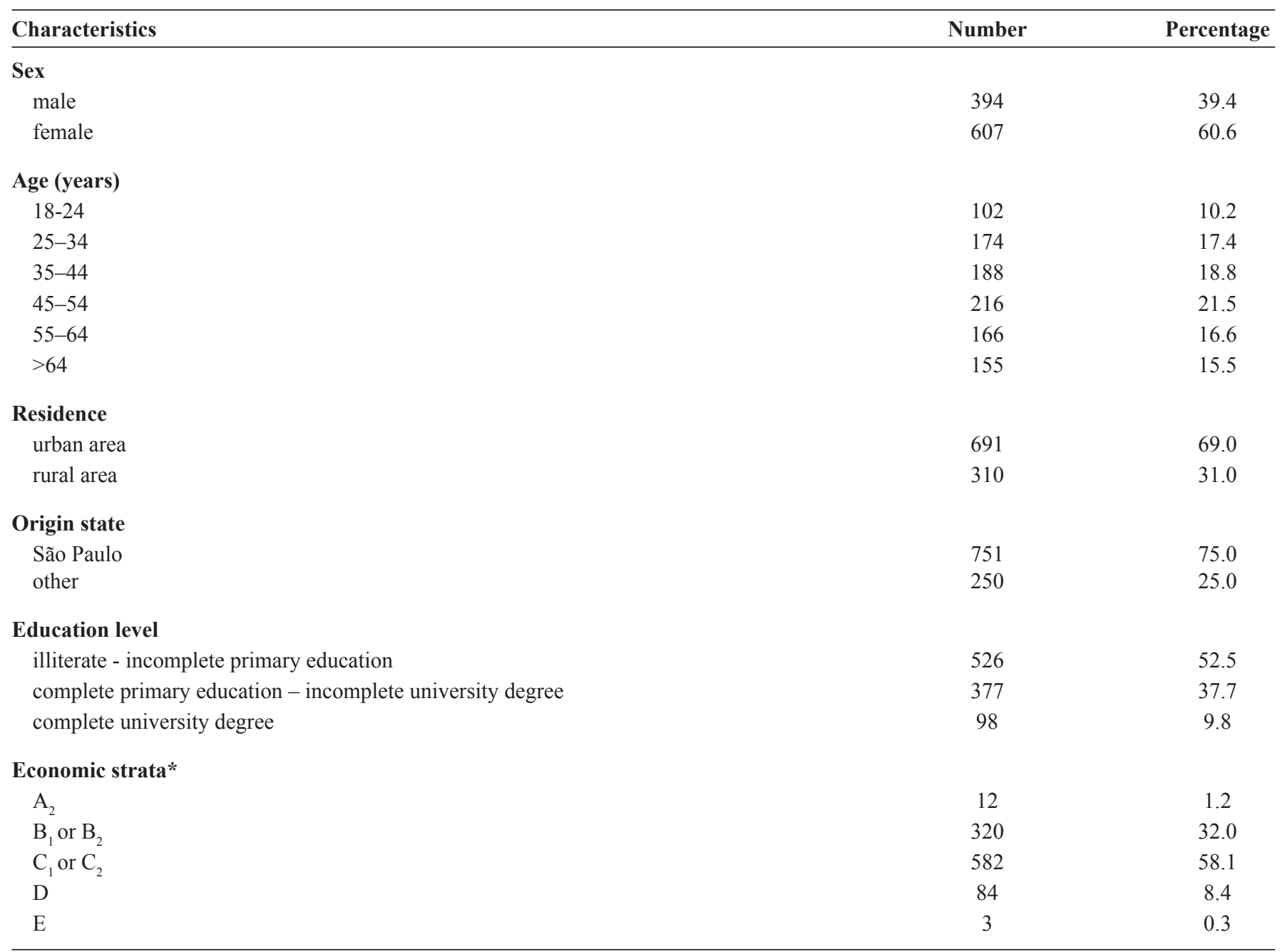

*Criteria Brazil Economic Classification ${ }^{(10)}$. 
TABLE 2 - Prevalence of hepatitis B and C serologic markers among the 1,001 study participants in Cássia dos Coqueiros, State of São Paulo, 2011-2013.

\begin{tabular}{lccc}
\hline Serologic markers & Number & Percentage & 95\% confidence interval \\
\hline HBsAg & 1 & 0.1 & $(0.0-0.6)$ \\
Anti-HBc & 41 & 4.1 & $(3.0-5.5)$ \\
Anti-HBc + HBsAg & 1 & 0.1 & $(0.0-0.6)$ \\
Anti-HBc + anti-HBs & 32 & 3.2 & $(2.1-4.5)$ \\
Isolated anti-HBc & 8 & 0.8 & $(0.5-1.9)$ \\
Isolated anti-HBs & 178 & 17.8 & $(15.5-20.3)$ \\
Anti-HCV & 4 & 0.4 & $(0.2-1.0)$ \\
\hline
\end{tabular}

HBsAg: hepatitis B surface antigen; anti-HBc: antibody against hepatitis B core antigen; anti-HBs: antibody to hepatitis B surface antigen. Anti-HCV: hepatitis C virus antibody.
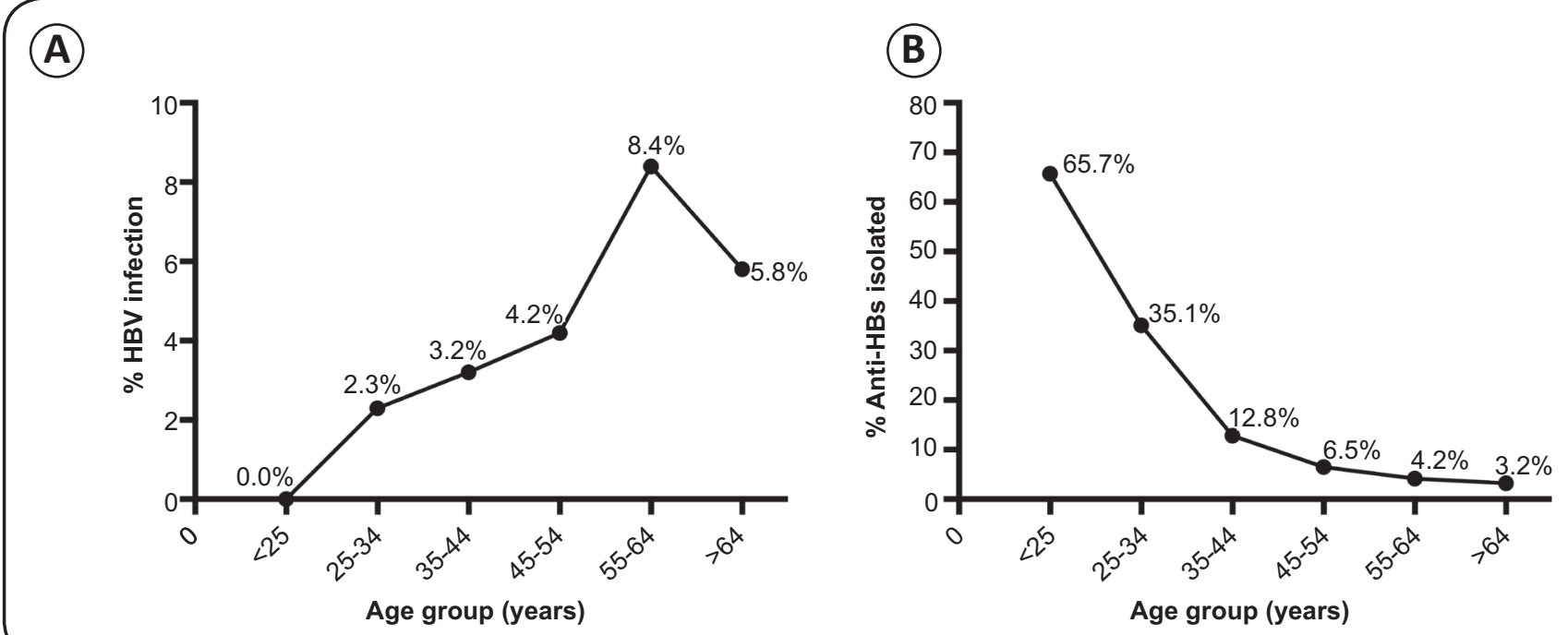

FIGURE 1 - A. Positive results for hepatitis B markers and B. The isolated hepatitis B surface antibody (anti-HBs) marker, according to age group in Cássia dos Coqueiros, State of São Paulo, 2011-2013. HBV: hepatitis B virus; anti-HBs: antibody to hepatitis B surface antigen.

was not statistically significant (Table 3). A progressive increase in positivity by age was observed, with the highest prevalence (8.4\%) observed in the 55-64-year-old group $(\mathrm{p}=0.009)$.

Regarding education level, similar positive results were observed in those who were illiterate and/or had an incomplete primary education $(5.5 \%)$ and in those who completed a university degree $(5.1 \%)$. Both groups had a higher number of positive results than the group with a complete primary education or incomplete university degree (2.1\%). Participants born in other Brazilian states had a 3-times higher prevalence than the natives of the State of São Paulo $(p=0.0004)$.

Individuals with lower economic levels (D and $\mathrm{E}$ ) had a prevalence twice as high as those with a better economical classification; this was not statistically significant. Higher rates of HBV infection were also observed among participants with the following characteristics: occupations involving contact with body fluids, such as tattooing, and history of hospitalization. HBV infection was significantly associated with a history of hepatitis B $(p=0.0001)$; risky sexual activity, as evidenced by the number of partners over a lifetime $(p=0.21)$ or over the last 6 months $(\mathrm{p}=0.008)$ and history of sexually transmitted disease $(\mathrm{STD})(\mathrm{p}=0.039)$; and previous use of glass syringes $(\mathrm{p}=0.28)$.

In the multivariate logistic regression model, age, being born in another Brazilian state other than São Paulo, tattoos, history of hepatitis, and $\geq 2$ sexual partners in the last 6 months were independently associated with HBV infection (Table 4).

The one $(0.1 \%)$ case of confirmed HCV infection was a 37-year-old man born in the State of São Paulo who had lived in the rural area of Cássia dos Coqueiros for more than 10 years. He was classified in the B2 economic stratum, had attended high school, and reported a history of hepatitis with a medical diagnosis of type $\mathrm{C}$. This man denied blood transfusion, 
TABLE 3 - Association between some risk factors and hepatitis B viral infection among study participants in Cássia dos Coqueiros, State of São Paulo, 2011-2013.

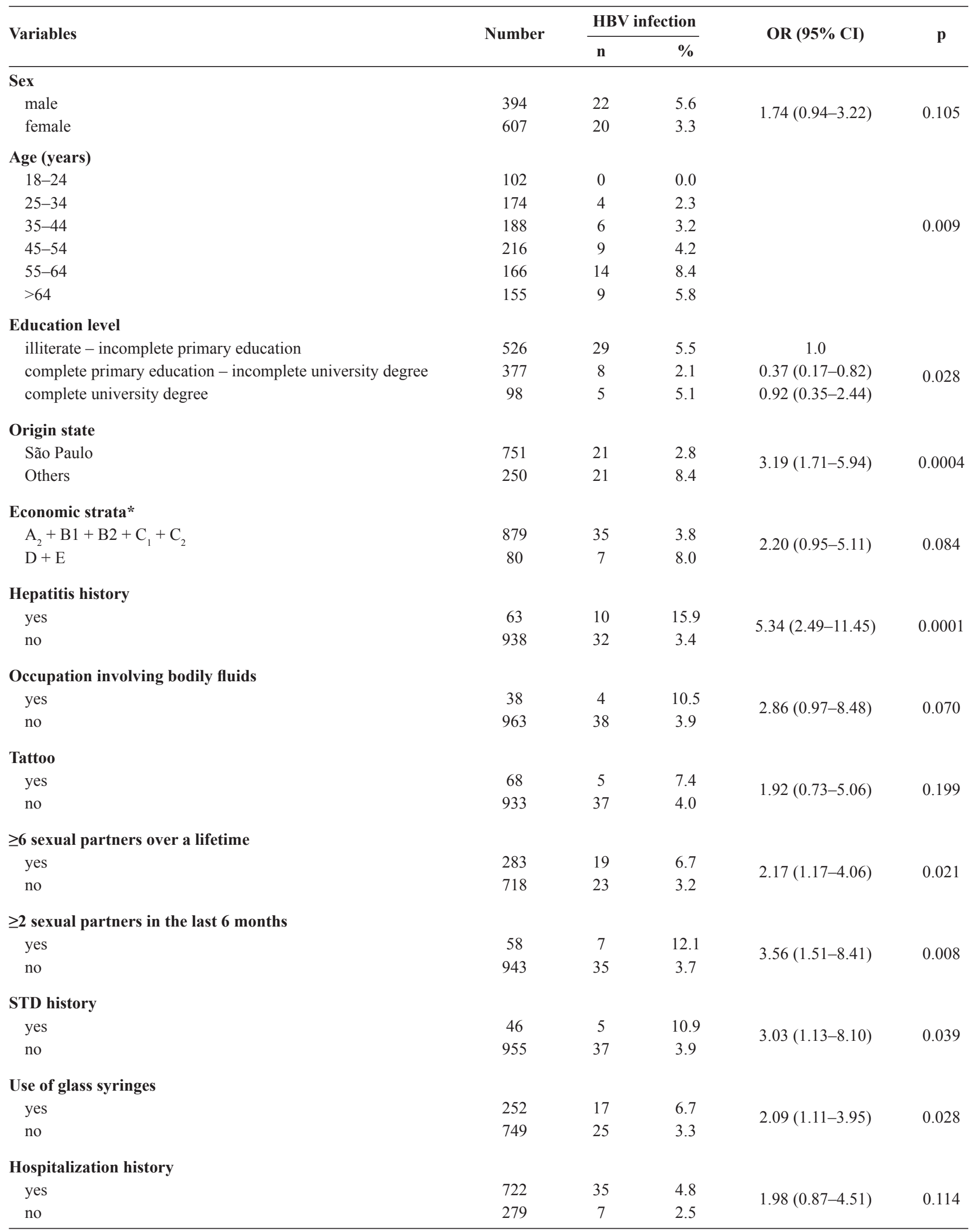

HBV: hepatitis B virus; OR: odds ratio; CI: confidence interval; STD: sexually transmitted disease. *Criteria Brazil economic classification ${ }^{(10)}$. 
TABLE 4 - Final logistic regression model testing the association between some risk factors and hepatitis B viral infection among study participants in Cássia dos Coqueiros, State of São Paulo, 2011-2013.

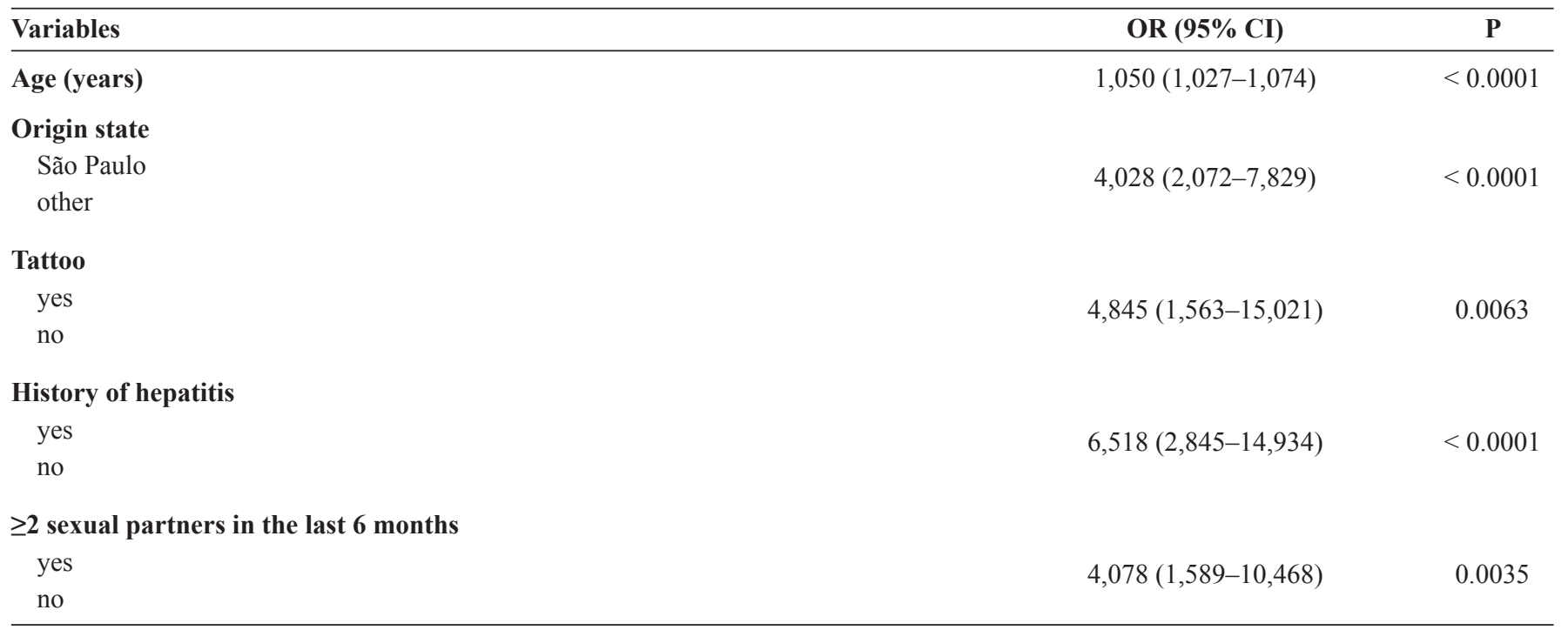

OR: odds ratio; CI: confidence interval.

hemodialysis, accidents with sharp objects, contact with bodily fluids, tattoos, piercing, occupation as a health professional, a past STD, imprisonment, consuming illicit drugs, sex with drug users, and sharing syringes/needles. He reported no more than 5 sexual partners over a lifetime or 2 partners in the last 6 months. He reported previous hospitalization and previous use of glass syringes.

\section{DISCUSSION}

This study demonstrated extremely low prevalences of hepatitis $\mathrm{B}$ and $\mathrm{C}$ markers in the municipality of Cássia dos Coqueiros. The current prevalence of hepatitis B was lower than that $(7.7 \%$ of total markers) in another investigation conducted in the city almost 25 years ago ${ }^{(8)}$. This might be the result of improved serological tests with fewer false-positive results.

In addition, the prevalence of HBV infection in Cássia dos Coqueiros was lower than those obtained both in the Brazilian state capitals as a whole (7.4\%) and in the Southeastern state capitals $(6.3 \%)$, as reported by a national survey published in $2010^{(11)}$. Other seroepidemiological studies conducted in the State of São Paulo also revealed higher prevalences of $\mathrm{HBV}$ infection ${ }^{(12)}$.

The implementation of the hepatitis B vaccine in the late 1990s likely contributed to the low levels of transmission. It was initially restricted to newborns and children throughout the national territory, subsequently extended to everyone $<20$ years old, and, since 2013 , made available to all individuals aged up to 50 years $^{(13)}$. It is $80-$ $100 \%$ effective in preventing infection or clinical disease in those who undergo the full scheme ${ }^{(14)}$.

In the present study, $17.8 \%$ of the participants had isolated anti-HBs, suggesting previous vaccination against HBV. However, owing to a lack of access to the vaccination cards of the respondents, this cannot be considered the real vaccine coverage. Instead, the distribution of HBV markers according to age group suggests the impact of the vaccine in Cássia dos Coqueiros; no positive result for hepatitis B was observed among those up to 25 years of age, the group with a higher $(65.7 \%)$ percentage of isolated anti-HBs.

However, the highest prevalences of previous infection markers occurred in older people, precisely those with the lowest percentage of isolated anti-HBs. Nevertheless, even for younger people, the indirect estimation of vaccination coverage using the presence of anti-HBs markers $(68.7 \%)$ had not yet reached the $95 \%$ recommended by the Brazil's Health Ministry ${ }^{(15)}$.

The increasing trend in hepatitis B markers in Cássia dos Coqueiros cannot be explained solely by variation in vaccine coverage by age. The same pattern was previously observed in this locality ${ }^{(8)}$, with prevalence rates of $2.3 \%$ and $18.9 \%$ in the younger and older participants, respectively, long before the introduction of the specific vaccine. Several other studies have indicated the same phenomenon, especially in low endemic areas, where vertical transmission has no epidemiological significance and individuals are exposed in adolescence at the time when sexual activity begins in addition to other risk behaviors such as tattooing and drug use that accumulate over time ${ }^{(8)}(16)$.

Migration has been associated with a higher risk of hepatitis $\mathrm{B}$, potentially owing to the less favorable economic conditions of migrants, origin from geographical areas with high levels of hepatitis $\mathrm{B}$, or a combination of these factors ${ }^{(17)}$. This was described locally in the $1980 \mathrm{~s}^{(18)}$.

The association between tattooing and HBV infection in Cássia dos Coqueiros is supported by another study ${ }^{(19)}$. However, it is essential to recognize that the increased risk is not due to the tattooing process itself, but to the low hygienic conditions under which it is performed ${ }^{(19)}$. 
Understandably, a history of hepatitis was also independently associated with infection markers, similar to the results obtained in people undergoing blood collection in health units in Ribeirão Preto, São Paulo, Brazil ${ }^{(20)}$. The authors warned that this association is not always reported, because approximately $50-90 \%$ of hepatitis B cases have no clinical symptoms, leading to a high proportion of missed diagnoses.

Having at least 2 sexual partners in the last 6 months was the final variable independently associated with $\mathrm{HBV}$ infection. Variables related with sexual activity have been consistently important for HBV transmission, particularly in low endemic areas, where dissemination of the virus is generally associated with unsafe sexual activity and multiple partners, rather than vertical transmission $^{(12)(13)}$. This becomes more evident in the disadvantaged social context such as in peripheral areas, where environmental factors, added to risky behavior, generate ideal conditions for maintaining the HBV in circulation ${ }^{(15)(16)}$.

Our results demonstrate that there have been few changes in the pattern of HBV circulation in Cássia dos Coqueiros and the low transmission rate is derived mainly from the availability of a specific vaccine against HBV. The immunized cohort grows with time and tends to create an increasing pattern of protection that allows consideration of a possible interruption in transmission in the medium term, assuming that coverage is improved and permanently maintained at high levels.

Regarding HCV, only 4 individuals had antibodies to hepatitis $\mathrm{C}$, and only one person was confirmed as a carrier of $\mathrm{HCV}$ genotype 3 using molecular biology techniques. Because genotype 3 is the second most often described in Brazil to genotype 1, the presence of genotype 3 in the confirmed HCV infection is not surprising ${ }^{(16)}$. Despite the very low prevalence of HCV serological markers in Cássia dos Coqueiros, it appears to be similar to those in other Brazilian populations ${ }^{(21)}$, but contrasting those of some population-based surveys in Brazil. The national survey of viral hepatitis, published in 2010, is an important example for comparison purposes, since it revealed a prevalence of $1.38 \%$ for viral exposure markers (anti-HCV) in the Brazilian capitals ${ }^{(11)}$. Similar results were reported by other authors in different parts of the country ${ }^{(22)}$.

However, there are specific sites and populations where extremely high prevalences are detected, such as inhabitants of Bebedouro district, São Paulo, Brazil ${ }^{(23)}$ and former soccer and basketball athletes who practiced between 1950 and $1970^{(24)}$. In both cases, sharing of possibly contaminated syringes and needles was likely the most important mechanism for transmission, as reported in different parts of the world for injectable drug users ${ }^{(25)}$. In Brazil, an estimated $50 \%{ }^{(26)}$ and $83 \%{ }^{(27)}$ of injectable drug users in São Paulo were reportedly affected with HCV.

Hemodialysis is also strongly associated with an increased risk for hepatitis $\mathrm{C}^{(28)}$. The limited use of hemodialysis and injectable drugs might be at least partially responsible for the fewer people with serological markers of both types of hepatitis infection in Cássia dos Coqueiros. In the present study, only 26 participants admitted to using inhaled or smoked illicit drugs, one person reported using injectable drugs, and 6 individuals were undergoing hemodialysis.
Some biosecurity practices that are currently adopted on a large scale, including routine screening of blood, organ, or semen donors; rigorous implementation of nosocomial infection control practices; and identification and counseling of people at high risk of $\mathrm{HCV}$ infection, have contributed to the reduced $\mathrm{HCV}$ circulation in the general population because they are all highly effective primary prevention measures in controlling viral dissemination ${ }^{(29)}$.

Also, the recent introduction of biosafety techniques should be mentioned, not only in health services but also in other places potentially capable of transmitting the infection, such as aesthetic clinics, beauty salons, and tattoo studios ${ }^{(30)}$. However, the effectiveness of these measures depends on appropriate education and training of health professionals and the general public, especially regarding safe techniques for injectable applications, sterilization, and disinfection procedures and stopping the reuse and sharing of potentially contaminated equipment and materials ${ }^{(30)}$.

Because there is only one health center in Cássia dos Coqueiros, which was created by and has always been under the administration of the Ribeirão Preto Medical School, there is close contact between the local population and university personnel. The observed behavioral patterns of the residents have changed over the last 20 years, including the adoption of practices that increase the risk for infection with HBV and $\mathrm{HCV}$, such as sexual promiscuity and illegal drug use. Despite these changes, transmission of both viruses occurs at very low levels. Several factors are likely to have contributed to this favorable situation locally, particularly the large-scale use of the hepatitis B vaccine, few illicit injectable drug users, and frequent educational measures directed at acquired immunodeficiency syndrome (AIDS) prevention among youths.

It is fundamental to maintain all of these highly effective and low-cost primary health care activities, which are potentially able to even interrupt local hepatitis B transmission in the midterm. Considering the similarities with other small, rural-like communities, it might be possible to at least partially generalize these results to other places in the Brazilian islands, for which there is a scarcity of epidemiological information on viral hepatitis.

The limitations of this study include the lack of participants younger than 18 years, resulting in the inability to estimate the prevalences of the whole population, and the lower adherence of men, who generally have a higher probability of HBV and $\mathrm{HCV}$ infections.

\section{CONFLICT OF INTEREST}

The authors declare that there is no conflict of interest.

\section{REFERENCES}

1. Taye S, Abdulkerim A, Hussen M. Prevalence of hepatitis B and $\mathrm{C}$ virus infections among patients with chronic hepatitis at Bereka Medical Center, Southeast Ethiopia: a retrospective study. BMC Res Notes 2014; 7:272. 
2. World Health Organization (WHO). Hepatitis B (Internet). WHO; 2014. (Accessed 2014 December 12). Available at www.who.int/ immunization_delivery/new_vaccines/en/index.html.

3. Myers RP, Krajden M, Bilodeau M, Kaita K, Marotta P, Peltekian K, et al. Burden of disease and cost of chronic hepatitis $\mathrm{c}$ virus infection in Canada. Can J Gastroenterol Hepatol 2014; 28:243-250.

4. Toy M. Cost-Effective Interventions in the Control of Chronic Hepatitis B (Chb) Infection. EMJ Hepatol 2014; 1:71-76.

5. Ministério da Saúde. Secretaria de Vigilância em Saúde. Brasil. Sistema de Informações sobre Mortalidade. Óbitos de hepatite B. Brasil, grandes regiões e unidades federadas 2000-2007. BRASIL; 2014. (Accessed 2014 November 15). Available at http://portal. saude.gov.br/portal/arquivos/pdf/obito_hepatite_b.pdf.

6. Negro F. Epidemiology of hepatitis C in Europe. Dig Liver Dis 2014; 46 Suppl 5:S158-64

7. World Health Organization (WHO). Hepatitis C (Internet). WHO; 2014. (Accessed 2014 November 10). Available at http://www.who. int/csr/disease/hepatitis/Hepc.pdf.

8. Passos ADC, Gomes UA, Figueiredo JFC, Nascimento MMP, Oliveira JM, Gaspar AMC, et al. Prevalência de marcadores sorológicos de hepatite B numa pequena comunidade rural do Estado de São Paulo, Brasil. Rev Saude Publica 1992; 26:119-24.

9. Instituto Brasileiro de Geografia e Estatística (IBGE). Cássia dos Coqueiros-MT (Internet). IBGE; 2014. (Accessed 2014 December 05). Available at http://www.ibge.gov.br/cidadesat/topwindow.htm?1.

10. Associação Brasileira de Empresas de Pesquisa (ABEP). Critério de Classificação Econômica Brasil (Internet). ABEP; 2014. (Accessed 2014 December 10). Available at www.abep.org

11. Ministério da Saúde (MS). Secretaria de Vigilância em Saúde. Estudo de prevalência de base populacional das infecções pelos vírus das hepatites A, B e C nas capitais do Brasil. Brasília DF: MS; 2010. 295 p.

12. Valente VB, Covas DT, Passos ADC. Marcadores sorológicos das hepatites B e C em doadores de sangue do Hemocentro de Ribeirão Preto, SP. Rev Soc Bras Med Trop 2005; 38:488-492.

13. Centro de Vigilância Epidemiológica. Aspectos Epidemiológicos das Hepatites Virais B e C no Estado de São Paulo, 2007-2013. BE CVE 2013; 3:1-28.

14. Poovorawan Y, Chongsrisawat V, Theamboonlers A, Leroux-Roels G, Crasta PD, Hardt K. Persistence of antibodies and immune memory to hepatitis B vaccine 20 years after infant vaccination in Thailand. Vaccine 2010; 28:730-736.

15. Ministério da Saúde. Secretaria de Vigilância em Saúde. Programa Nacional de Imunizações 30 anos. Brasília, DF: MS; 2003. 208 p.

16. Pereira LM, Martelli CM, Merchán-Hamann E, Montarroyos UR, Braga MC, Lima ML, et al. Population-based multicentric survey of hepatitis B infection and risk factor differences among three regions in Brazil. Am J Trop Med Hyg 2009; 81:240-247.
17. Reekie J, Gidding HF, Kaldor JM, Liu B. Country of birth and other factors associated with hepatitis B prevalence in a population with high levels of immigration. J Gastroenterol Hepatol 2013; 28:1539-1544.

18. Passos ADC, Gomes UA, Figueiredo JFC, Nascimento MMP, Oliveira JM, Gaspar AMC. Influência da migração na prevalência de marcadores sorológicos de hepatite B em comunidade rural. 1Análise da prevalência segundo local de nascimento. Rev Saude Publica 1993; 27:30-35.

19. Jafari S, Buxton JA, Afshar K, Copes R, Baharlou S. Tattooing and Risk of Hepatitis B: A Systematic Review and Meta-analysis. Can J Public Health 2012; 103:207-212.

20. Miranda LVG, Passos ADC, Figueiredo JFC, Gaspar AMC, Yoshida CFT. Marcadores sorológicos de hepatite B em indivíduos submetidos a exames de sangue em unidades de saúde. Rev Saude Publica 2000; 34:286-291.

21. Rodrigues-Neto J, Cubas MR, Kusma SZ, Olandoski M. Prevalência da hepatite viral $\mathrm{C}$ em adultos usuários de serviço público de saúde do município de São José dos Pinhais - Paraná. Rev Bras Epidemiol 2012; 15:627-638.

22. Zarife MAS, Silva LK, Silva MB, Lopes GB, Barreto ML, Teixeira $\mathrm{MG}$, et al. Prevalence of hepatitis $\mathrm{C}$ virus infection in north-eastern Brazil: a population-based study. Trans R Soc Trop Med Hyg 2006; 100:663-668

23. Ferrão SBRL, Figueiredo JFC, Yoshida CFT, Passos ADC. Prevalência elevada de hepatite $\mathrm{C}$ no distrito de Botafogo, cidade de Bebedouro, interior do Estado de São Paulo, Brasil, 2007. Cad Saude Publica 2009; 25:460-464.

24. Passos ADC, Figueiredo JF, Martinelli AL, Villanova M, Nascimento MM, Secaf M. Hepatitis C among former athletes: association with the use of injectable stimulants in the past. Mem Inst Oswaldo Cruz 2008; 103:809-812.

25. Nelson PK, Mathers BM, Cowie B, Hagan H, Jarlais DD, Horyniak $\mathrm{D}$, et al. Global epidemiology of hepatitis B and hepatitis C in people who inject drugs: results of systematic reviews. Lancet 2011; 378:571-583.

26. Brito VOC, Parra D, Facchini R, Buchalla CM. Infecção pelo HIV, hepatites B e C e sífilis em moradores de rua, São Paulo. Rev Saude Publica 2007; 41:47-56.

27. Marchesini AM, Prá-Baldi ZP, Mesquita F, Bueno R, Buchalla CM. Hepatites B e C em usuários de drogas injetáveis vivendo com HIV em São Paulo, Brasil. Rev Saude Publica 2007; 41:57-63.

28. Khodir SA. Prevalence of HCV Infections Among Hemodialysis Patients in Al Gharbiyah. Arab J Nephrol Transplant 2012; 5:145-147.

29. Kew M. Prevention of hepatitis C virus infection. J Viral Hepat 2004; 11:198-205.

30. Lavanchy D. Evolving epidemiology of hepatitis C virus. Clin Microbiol Infect 2011; 17:107-115. 